SĄD KOLEŻEŃSKI

Przewodniczacy:

ks. bp dr Stefan CICHY

Członkowie:

ks. doc. dr hab. Jerzy CHMIEL

ks. prof. dr hab. Stanisław PISAREK

Kraków

KS. KAZIMIERZ PANUŚ

ks. Jerzy Chmiel

\title{
MEDAL POLSKIEGO TOWARZYSTWA TEOLOGICZNEGO DLA KS. NORBERTA HÖSLINGERA
}

W niedzielę, 5 września 1999 r., w pięknie położonym opactwie Neustift, koło Brixen-Bressanone w Górnej Adydze (północne Włochy), ks. dr Norbert Höslinger otrzymał medal Polskiego Towarzystwa Teologicznego w Krakowie.

Ks. Höslinger od roku 1966 był dyrektorem Austriackiego Katolickiego Dzieła Biblijnego (Österreichisches Katholisches Bibelwerk) z siedzibą w Klosterneuburg k. Wiednia. Przez ponad 30 lat wspomagał polskich biblistów w chwilach trudnych; bywał w Polsce wygłaszając konferencje. Założył sekcję środkowoeuropejską (Region Mitteleuropa AMB) Katolickiej Federacji Biblijnej, która to sekcja odbywała właśnie spotkanie w opactwie Neustift. Z chwilą jego odejścia na emeryturę Polskie Towarzystwo Teologiczne w Krakowie, odznaczając ks. Höslingera medalem, chciało w ten sposób wyrazić mu wdzięczność za wszystko, co zrobił dla Polski, a szczególnie dla środowiska krakowskiego.

Medal wręczył ks. Jerzy Chmiel, wygłaszając przy okazji krótką laudację po niemiecku i po łacinie. Oto łaciński fragment laudacji, który zaintrygował zebranych bardziej formą niż treścią:

„Epigramma pro Doctore Norberto Höslinger:

Servi inutiles sumus

Donec nos protrahat humus

Et hoc est Dei instinctu.

Sed Libri Sacri perenni

Ex Dei ore sunt dati

Ut Via Veritas Vita

Scripturae servus nobilis 
Est Doctor Vindobonensis

Norbertus Höslingerius

Laudamus eius opera

Quae in re fecit biblica

Deus sit ei praemium".

A o regionalnym spotkaniu sekcji środkowoeuropejskiej (AMB) Katolickiej Federacji Biblijnej w dniach od 5 do 8 września 1999 r. w opactwie Neustift (Abbatia Novacella) w następnych numerach RBL.

Kraków

KS. JERZY CHMIEL

\section{TEMATY ROZPRAW DOKTORSKICH Z ZAKRESU BIBLISTYKI}

\section{NA PAPIESKIM WYDZIALE TEOLOGICZNYM W KRAKOWIE}

KS. CHŁĄD STANISŁAW (diecezja częstochowska), 1980, Kościół „widowiskiem aniołów" (na podstawie pism Nowego Testamentu),

promotor: o. prof. dr hab. Augustyn Jankowski OSB 29 ,

S. EHRLICH Konstancja EMILIA OSU (urszulanka), 1974, Teologia Psalmu

promotor: ks. prof. dr hab. Stanisław Grzybek

JELONEK TOMASZ BOLESŁAW, 1974, „Kościót pierworodnych zapisanych w niebiosach" (Hbr 12, 23a). Przyczynek do eklezjologii Nowego Testamentu,

promotor: o. prof. dr hab. Augustyn Jankowski OSB

KS. ŁACH JÓZEF (diecezja tarnowska), 1977, Hesed i hasîd w świetle Psalterza, promotor: ks. prof. dr hab. Stunisław Grzybek

O. MYCIELSKI STANISLAW LUDWIK OSB (benedyktyn), 1971, Dzień paruzji Chrystusa wedlug Listu do Tesaloniczan. Obraz a treść teologiczna,

promotor: o. prof. dr hab. Augustyn Jankowski OSB 